\title{
Evaluation of the Extracts of Piper guineense for Antibacterial Activity Against Spoilage Bacteria of Rivers State 'Native' Soup.
}

\author{
Eruteya, O. C*., Ire, F. S and Aneke, C. C \\ Department Of Microbiology, University Of Port Harcourt, Port Harcourt, Nigeria.
}

\begin{abstract}
The study examined the sensitivity of spoilage bacteria to crude ethanol, methanol and aqueous extracts of Piper guineense employed in the preparation of the Rivers State 'native' soup and also determined the proximate composition using standard methods. The resulting bacteria following conventional and molecular characterization were: Providencia rettgeri strain RCB 200 (22.2\%), Proteus vulgaris strain 20141026 (5.6\%), Pseudomonas aeruginosa strain 335K55 (44.4\%), Lysinbacillus sphaericus III (11.1\%) and Alcaligenes faecalis strain L48 (16.7\%). The ethanol $(150-250 \mathrm{mg} / \mathrm{mL})$ and methanol $(50-250 \mathrm{mg} / \mathrm{mL})$ extracts inhibited only Pseudomonas aeruginosa strain 335K55 with zones of inhibition ranging from 7 to $9 \mathrm{~mm}$ and 7 tol $1 \mathrm{~mm}$ respectively. None of the isolates were sensitive to the aqueous extract. The proximate analysis shows the chemical composition such as moisture (78.02\%), ash (1.65\%), carbohydrate $(4.95 \%)$, protein $(5.32 \%)$, lipid (4.37\%) and fibre (5.69\%). The study demonstrated the potential application of Piper guineense in the control of Pseudomonas aeruginosa strain 335K55, a prominent food spoilage bacterium.
\end{abstract}

Keywords: Spice extract, 'native' soup, Piper guineense, proximate, spoilage.

\section{Introduction}

Food spoilage is a gradual process resulting from one or a combination of the following factors: poor sanitation, enzymatic or chemical reactions, storage temperature and microbial growth. The main single cause of food spoilage is invasion by microorganisms such as moulds, yeast and bacteria; with bacteria mostly implicated. The inhibition of the growth and activities of microorganisms is one of the major purposes for the use of chemical preservatives in the food industry because they are capable of inhibiting microbial growth by interfering with cell membranes, enzyme activity or genetic mechanisms of the microorganisms $[1,2]$. However, the use of chemical preservatives in the prevention of pathogenic and spoilage microorganisms in foods has lead to negative health effects [3]. This upsurge in the prevalence of health effects of many synthetic antimicrobial agents and incidence of multidrug resistant bacteria has spurred scientists on the research for plant based antimicrobial of therapeutic [4] and food preservative potentials. Spices are natural preservatives and so they have advantage over chemical preservatives which consumers now shy away from due to their negative health effects and the resistance that microorganisms develop towards some of them. Spices are used as condiments and ingredients in foods. In Nigeria, some are used for the preparation of certain type of soups which are delicacies and also recommended for fast relief of ailments such as malaria fever [5].

Piper guineense, commonly referred to as African black pepper or Ashanti pepper is a condiment for the Rivers State 'native' soup, popular among the Ikwerre tribe, but consumed by other tribes in Rivers State and the South - South and South- Eastern part of Nigeria. Other components of the soup include: stock fish, dry fish, cocoa yam as thickener, palm oil, periwinkles, and condiments to taste. The soup are usually prepared for nursing mothers from the first day of delivery to prevent post partum contraction and to aid in the fast return of the uterine muscles to the original shape, and increase the flow of the nursing mothers' breast milk [6]. Soups in Nigeria serve as a common denominator for eating several other Nigerian foods. The popular Nigerian 'eba' (garri), 'fufu' and yam do not go without a delicious soup.

Piper guineense belongs to the family piperaceae and has more than 700 species [4]. It is commonly found in the tropical regions of Central and Western Africa. It is cultivated in countries such as Nigeria, where it is used as flavorings for stew and local delicacies $[7,8,9]$. In Nigeria, it is known by various vernacular names such as 'uziza' in Igbo; 'iyere' in Yoruba; 'etinghene' in Efik and 'odusa' in Ibibio [4, 10, 11, 12]. Piper guineense have nutritional and non nutritional factors which are responsible for its aroma, flavor and preservative properties $[6,13]$. The fruits of Piper guineense (which is the part of the plant that is traditionally used) are rich in a wide range of natural products including volatile oils, lignans, amides, alkaloids, tannins, Saponins, flavonoids, terpenoids and polyphenols $[6,9]$. The antimicrobial activity of $P$. guineense against Esherichia coli, Staphylococcus aureus, Pseudomonas aeruginosa, Bacillus subtilis, Shigella sp, Salmonella sp, Klebsiella pnemonium, Staphylococcus aureus (ATCC 25923), Bacillus sp. and Enterococcus faecalis have been reported $[4,11,12,14,15]$.

There is however, a dearth of information on the antimicrobial activity of $P$. guineense on spoilage bacteria of Rivers State 'native' soup hence, the objective of our study is to evaluate its effects on possible 
spoilage bacteria with a view to establishing the likely role of this spices in enhancing the soup's shelf-life. The introduction of the paper should explain the nature of the problem, previous work, purpose, and the contribution of the paper. The contents of each section may be provided to understand easily about the paper.

\subsection{Sample collection}

\section{MATERIALS AND METHODS}

The soup ingredients comprising 'uziza' (Piper guineense) stock fish, dry fish, cocoa yam as thickener, palm oil, periwinkles, prawn and condiments were purchased at the Choba Junction market, Port Harcourt.

\subsection{Preparation of 'native' soup}

The soup was prepared using the traditional method. The meat was first parboiled for 30-50 min before adding the washed dry/stock fish and additional water. Once, they appear soft, palm oil, crayfish and ground pepper was added. The soup was cooked for $10 \mathrm{~min}$ before adding salt and magi to taste. Cocoyam was thereafter added and allowed to dissolve for 8-10 min. Periwinkle, prawn and 'uziza' leaves were then added and allowed to simmer for another $5 \mathrm{~min}$ for the soup to be ready for consumption.

\subsection{Proximate analysis}

The moisture, crude protein, crude fibre, crude fat, carbohydrate and total ash contents of the soup was analysed using the method described by Association of Official Analytical Chemists' [16].

\subsection{Isolation procedure}

Ten millilitre $(10 \mathrm{ml})$ of an overnight and deteriorating soup (after $24 \mathrm{~h}$ ) was aseptically transferred to $90 \mathrm{ml}$ sterile peptone water and homogenized. After a ten-fold serial dilution, $0.1 \mathrm{ml}$ was spread plated on Nutrient agar plates and incubated at room temperature $\left(29 \pm 2^{\circ} \mathrm{C}\right)$ for $24 \mathrm{~h}$. Distinct colonies were purified in fresh Nutrient agar and stored in slants for further analysis.

\subsection{Identification of bacterial isolates}

The isolates were identified using standard conventional (Gram staining, catalase, indole, motility, citrate, Methyl red, Voges Proskauer, oxidase, starch hydrolysis, $\mathrm{H}_{2} \mathrm{~S}$ production, sugar utilization) and molecular methods (Polymerase Chain Reaction and sequencing).

\subsubsection{DNA extraction}

Extraction was done using a ZR fungal/bacterial DNA mini prep extraction kit supplied by Inqaba South Africa. A heavy growth of the pure culture of the isolates was suspended in 200 microlitre of isotonic buffer into a ZR Bashing Bead Lysis tubes, 750 microlitre of lysis solution was added to the tube. The tubes were secured in a bead beater fitted with a $2 \mathrm{ml}$ tube holder assembly and processed at maximum speed for 5 min. The ZR bashing bead lysis tubes were centrifuged at 10,000xg for $1 \mathrm{~min}$. Four hundred (400) microlitres of supernatant was transferred to a Zymo-Spin IV spin Filter (orange top) in a collection tube and centrifuged at $7000 \mathrm{xg}$ for $1 \mathrm{~min}$. One thousand two hundred (1200) microlitres of fungal/bacterial DNA binding buffer was added to the filtrate in the collection tubes bringing the final volume to 1600 microlitre, 800 microlitre was then transferred to a Zymo-Spin IIC column in a collection tube and centrifuged at 10,000xg for $1 \mathrm{~min}$, the flow through was discarded from the collection tube. The remaining volume was transferred to the same Zymo-spin and spun. Two hundred (200) microlitre of the DNA Pre-Wash buffer was added to the Zymo-spin IIC in a new collection tube and spun at 10,000xg for $1 \mathrm{~min}$ followed by the addition of $500 \mathrm{microlitre}$ of fungal/bacterial DNA Wash Buffer and centrifuged at 10,000xg for $1 \mathrm{~min}$. The Zymo-spin IIC column was transferred to a clean 1.5 microlitre centrifuge tube, 100 microlitre of DNA elution buffer was added to the column matrix and centrifuged at 10,000xg microlitre for $30 \mathrm{~s}$ to elude the DNA. The ultra pure DNA was then stored at $-20^{\circ} \mathrm{C}$ for other downstream reaction.

\subsubsection{Amplification of 16S rRNA}

The 16S rRNA regions of the rRNA genes of the isolates were amplified using the $27 \mathrm{~F}$ (AGAGTTTGATCMTGGCTCAG): and 1492R (CGGTTACCTTGTTACGACTT): primers on an ABI 9700 Applied Bio-systems thermal cycler at a final volume of 50 microlitres for 35 cycles. The PCR mix included: the X2 Dream taq Master mix supplied by Inqaba, South Africa (taq polymerase, DNTPs, MgCl), the primers at a concentration of $0.4 \mathrm{M}$ and the extracted DNA as template. The PCR conditions were as follows: Initial denaturation, $95^{\circ} \mathrm{C}$ for $5 \mathrm{~min}$; denaturation, $95^{\circ} \mathrm{C}$ for $30 \mathrm{~s}$; annealing, $52^{\circ} \mathrm{C}$ for $30 \mathrm{~s}$; extension, $72^{\circ} \mathrm{C}$ for $30 \mathrm{~s}$ for 35 cycles and final extension, $72^{\circ} \mathrm{C}$ for $5 \mathrm{~min}$. The product was resolved on a $1 \%$ agarose gel at $120 \mathrm{~V}$ for 15 min and visualized on a UV transilluminator. 


\subsubsection{Sequencing of 16S rRNA}

The amplified 16S products were sequenced on a 3500 genetic analyzer using the Bigdye-Termination technique by Inqaba South Africa.

\subsubsection{Phylogenetic analysis}

The sequences were edited using the bioinformatics algorithm Bioedit, similar sequences were downloaded from the National Biotechnology Information Center (NCBI) data base using BlastN, these sequences were aligned using ClustalX. The evolutionary history was inferred using the Neighbor-Joining method in MEGA 6.0 [17]. The bootstrap consensus tree inferred from 500 replicates is taken to represent the evolutionary history of the taxa analyzed [18]. Branches corresponding to partitions reproduced in less than 50\% bootstrap replicates were collapsed. The evolutionary distances were computed using the Jukes-Cantor method [19] and are in the units of the number of base substitutions per site.

\subsection{Preparation of crude Extract}

The methanol and ethanol crude extracts of Piper guineense were prepared according to the method of Akujobi et al. [20]. The spice crude extracts were diluted with 30\% dimethylsulphoxide (DMSO) to obtain $250 \mathrm{mg} / \mathrm{ml}(0.5 \mathrm{~g}$ in $2 \mathrm{ml}), 200 \mathrm{mg} / \mathrm{ml}(0.5 \mathrm{~g}$ in $2.5 \mathrm{ml}), 150 \mathrm{mg} / \mathrm{ml}(0.3 \mathrm{~g}$ in $2 \mathrm{ml}), 100 \mathrm{mg} / \mathrm{ml}(0.5 \mathrm{~g}$ in $5 \mathrm{ml})$ and $50 \mathrm{mg} / \mathrm{ml}(0.25 \mathrm{~g}$ in $5 \mathrm{ml})$. Aqueous crude extract was diluted in sterile deionised water at same ratio.

\subsection{Antibacterial activity of crude Piper guineense extracts}

Agar diffusion method was employed. From an overnight broth culture of the various bacterial isolated in nutrient broth, a $1 \times 10^{8} \mathrm{cell} / \mathrm{ml}$ McFarland standard was prepared (by first centrifuging the overnight broth at 4,000 rpm for $10 \mathrm{~min}$ and supernatant decanted. Sterile deionized water $(2 \mathrm{ml})$ was then added vortexed and centrifuged again at 4,000 rpm for $10 \mathrm{~min}$. The resulting pellets were transferred to a physiological saline while comparing with McFarland standards) and $0.1 \mathrm{ml}$ aseptically transferred to sterile Petri dishes before adding 20 $\mathrm{ml}$ molten Mueller Hinton agar cooled to $50^{\circ} \mathrm{C}$. The content was thoroughly mixed and then allowed to solidify. Five wells $(5.0 \mathrm{~mm})$ were made in each plate using a cup borer and $0.2 \mathrm{ml}$ of the spice concentrations of the methanol, ethanol and aqueous extracts aseptically transferred into each well using a pipette. Plates were allowed to stand for prediffusion for $1 \mathrm{~h}$ before incubation at $29 \pm 2^{\circ} \mathrm{C}$ for $24 \mathrm{~h}$. Average zones of inhibition were calculated.

\subsection{Determination of spoilage time}

Fifty milliliter $(50 \mathrm{ml})$ of freshly prepared soup were aseptically dispensed into pre-sterilized bowl, and $0.1 \mathrm{ml}$ of $1 \times 10^{8} \mathrm{cell} / \mathrm{ml}$ McFarland standard of individual and a mixed bacteria culture was added to each bowl and observed at $15 \mathrm{~min}$ interval for spoilage signs at room temperature $\left(29 \pm 2^{\circ} \mathrm{C}\right)$.

\subsection{Proximate composition}

\section{RESULTS AND DISCUSSION}

Nigeria is rich in foods and diets that are good sources of micronutrients and supplements in a world faced with problem of food scarcity [21]. The result of the proximate composition of the 'native' soup is presented in Table 1. The moisture and nutrient content of the soup makes it an ideal medium for the growth of microorganisms and consequent spoilage. There is paucity of information on proximate composition of this soup but some of its parameters are comparable with some popular Nigerian soups, namely: 'ogbono' [moisture $(68.70 \%)$, ash $(4.55 \%)$, carbohydrate $(1.96 \%)$, protein $(18.70 \%)$, lipid $(6.12 \%)$ and fibre $(1.04 \%)]$, melon [moisture (62.97\%), ash (1.85\%), carbohydrate (16.36\%), protein (4.21\%), lipid (9.24\%) and fibre $(5.34 \%)$, 'ewedu' [moisture $(88.60 \%)$, ash $(1.81 \%)$, carbohydrate $(1.47 \%)$, protein $(6.00 \%)$, lipid $(1.05 \%)$ and fibre $(1.47 \%)$ ] and 'edikankong' [moisture $(58.12 \%)$, ash $(4.34 \%)$, carbohydrate $(7.56 \%)$, protein $(4.70 \%)$, lipid $(17.02 \%)$ and fibre $(8.16 \%)][21,22]$.

\subsection{Isolated bacteria}

The phylogenic tree of bacterial isolates from Rivers State 'native' soup is presented in Fig. 1. The most prevalent isolate was Pseudomonas aeruginosa strain 335K55 (44.4\%), followed by Providencia rettgeri strain RCB 200 (22.2\%) and the least was Proteus vulgaris strain 20141026 (5.6\%). Others are Alcaligenes faecalis strain L48 (16.7\%) and Lysinbacillus sphaericus III (11.1\%). The genera Pseudomonas, Alcaligenes and Proteus isolated from this soup are among important genera known to occur in foods [23, 24, 25], whereas, the genera Lysinbacillus and Providencia are not recognized foodborne bacteria. Liu et al. [26] have reported the presence of Pseudomonas sp. in native chicken soup in China.

\subsection{Spoilage potentials}


The result of the potentials of individual and a mixed bacteria culture to cause spoilage of 'native' soup is presented in Table 2. The average spoilage time for all seeded soups ranged from 15.15 to $16.00 \mathrm{~h}$ compared to the control samples' average spoilage time of $18.15 \mathrm{~h}$. There is a dearth of information on the spoilage microorganisms of Nigeria soups, however, a number of Authors have reported P. aeruginosa, Alcaligenes faecalis and Proteus vulgaris as major food spoilage bacteria of 'ugba' (African oil bean seeds), meat and dairy $[27,28,29,30,31,32,33]$.

\subsection{Antibacterial activity of $P$. guineense}

The results of the antibacterial activity of crude aqueous, ethanol and methanol extracts of $P$. guineense against the resulting isolates revealed that only the Pseudomonas aeruginosa strain 335K55 was sensitive to the ethanol and methanol extracts (Table 3). This finding is not in agreement with Ebana et al. [12] who reported the inability of ethanolic extract of $P$. guineense to inhibit $P$. aeruginosa, while aqueous extract did. Aboaba et al. [15] and Anyanwu and Nwosu [11] however, reported the inhibition of $P$. aeruginosa by both the aqueous and ethanol extract of $P$. guineense, with the ethanol zones of inhibition comparable to the finding of this study. The finding of this study is in agreement with reports by Osuala and Anyadoh [34] that methanolic extracts of $P$. guineense exhibited much more antibacterial activity against $P$. aeruginosa than the ethanolic extracts, recommending that methanol be used in preference to ethanol in extracting active ingredients from plants.

Figures and Tables

Table 1. Proximate composition of 'native' soup

\begin{tabular}{ll}
\hline Parameter & Composition (\%) \\
\hline Moisture & 78.02 \\
Ash & 1.65 \\
Carbohydrate & 4.95 \\
Protein & 5.32 \\
Lipid & 4.37 \\
Fibre & 5.69 \\
\hline
\end{tabular}

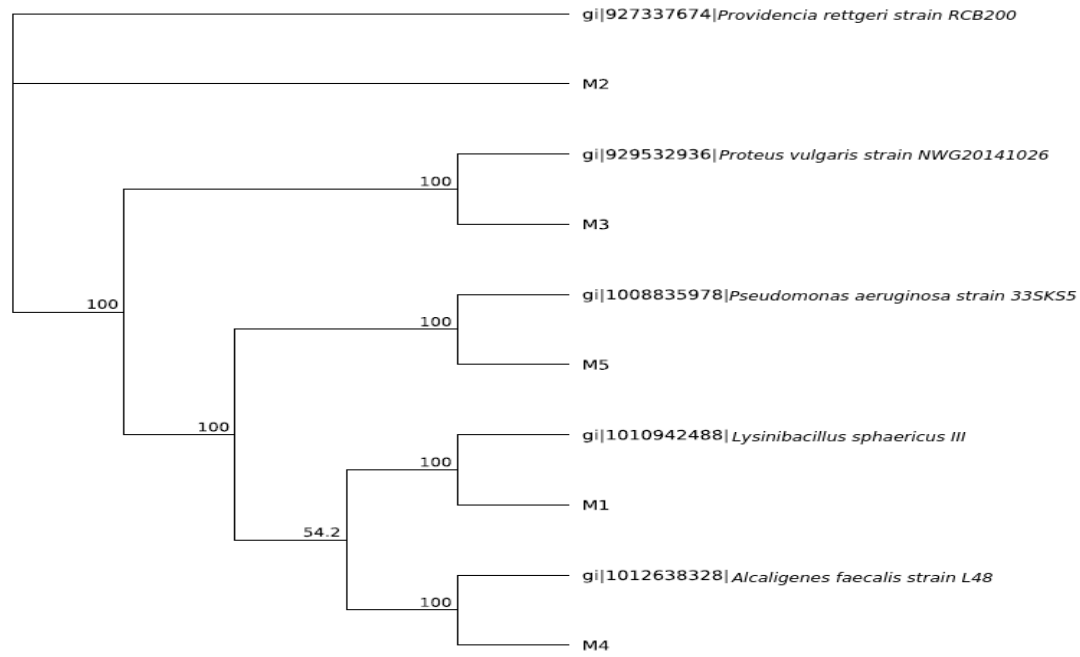

Figure 1: Phylogenic tree of isolated bacteria from Rivers State 'native' soup. 
Table 2 Spoilage time for individual and mixed bacteria culture

\begin{tabular}{lc}
\hline Bacteria & Average spoilage time (h) \\
\hline Pseudomonas aeruginosa strain 335K55 & 15.15 \\
Providencia rettgeri strain RCB 200 & 16.00 \\
Proteus vulgaris strain 20141026 & 16.00 \\
Alcaligenes faecalis strain L48 & 15.15 \\
Lysinbacillus sphaericus III & 16.00 \\
Mixed bacteria culture & 15.15 \\
Control & 18.15 \\
\end{tabular}

Table 3: Effects of ethanol and methanol extracts of P. guineense on Pseudomonas aeruginosa

\begin{tabular}{lcc}
\hline Extract concentration $(\mathrm{mg} / \mathrm{mL})$ & Average zones of inhibition $(\mathrm{mm})$ & \\
& Crude ethanol extract & Crude methanol extract \\
\hline 250 & 9 & 11 \\
150 & 8 & 10 \\
100 & 7 & 9 \\
50 & 0 & 8 \\
& 0 & 7 \\
\hline
\end{tabular}

\section{Conclusion}

The findings of this study have revealed the presence of notable spoilage bacteria, namely: Proteus vulgaris strain 20141026, Pseudomonas aeruginosa strain 335K55 and Alcaligenes faecalis strain L48 in Rivers State 'native' soup and the inhibitory potentials of $P$. guineense against $P$. aeruginosa strain 335K55. The inability of $P$. guineense to inhibit the other spoilage bacteria is also established. The bioactive component of $P$. guineense can be harnessed for the control of $P$. aeruginosa since the increase in the quantity of the spice will impact negatively on the acceptability of the soup.

\section{Acknowledgements}

The Authors are grateful to Prof. Tatfeng of the Niger Delta University, Bayelsa State and the Staff of the Plant Physiology Laboratory, Department of Plant Science and Biotechnology, University of Port Harcourt.

\section{References}

[1]. K. R. Fulton, Survey of industry on the use of food additives. Food Technology: 35(12), 1981, $80-81$

[2]. A. L.Branen, and P. M. Davidson, Antimicrobials in foods (New York:Marcel, Dekker Inc., 1983).

[3]. R. E. Uzeh, and D. O. Oguntosin, Efficacy of essential oils from some African spices against two strains of Bacillus cereus isolated from vegetable salad. Journal of Food Research, 2(6), 2013, 48-54.

[4]. O. C. Nwinyi, N. S. Chinedu, O. O. Ajani, C. O.Ikpe, and K. O. Ogunniran, Antibacterial effects of extracts of Ocimum gratissimum and Piper guineense on Escherichia coli and Staphylococcus aureus. African Journal of Food Science, 3 (3), $2009,77-$ 81 .

[5]. A. Sofowora, Medicinal plants and traditional medicine in Africa (Ibadan, Nigeria: Spectrum Books Ltd, 1993).

[6]. F. O. Uhegbu, O. Imo, and A. E. Ugbogu, Effect of aqueous extract of Piper guineense seeds on some liver enzymes, antioxidant enzymes and some hematological parameters in albino rats. International Journal of Plant Science and Ecology, 1(4), 2015, 167171.

[7]. P. C. Onyenekwe, G. H. Ogbadu, and S. Hashimoto, The effect of gamma radiation on the microflora and essential oil of Ashanti pepper (Piper guineense) berries. Postharvest Biology and Technology, 10 (2), 1997, 161-167. 
[8]. A. E. Agoha, Uses of Piper guineense fruits. Journal of Food Science. 10 (3), 2002, 231-238.

[9]. M. N. Opara, Some Edible Spices of Southeastern Nigeria with Antiparasitic Properties: A Review. American Journal of Ethnomedicine, 1(6), 2014, 384-392.

[10]. A. P. Ekanem, F. V. Udoh, and E. E. Oku, Effects of ethanol extracts of Piper guineense seeds (Schum and Thonn) on the conception of mice (Mus musculus). African Journal of Pharmacy and Pharmacology, 4 (6), 2010, 362-367.

[11]. C. U. Anyanwu, and G. C. Nwosu, Assessment of the antimicrobial activity of aqueous and ethanolic extracts of Piper guinense leaves. Journal of Medicinal Plant Research, 8(10), 2014, 436-440.

[12]. R. U. B. Ebana, U. O. Edet, U. M. Ekanemesang, G. M. Ikon, C. A. Etok, and A. P. Edet, Antimicrobial Activity, Phytochemical Screening and Nutrient Analysis of Tetrapleura tetraptera and Piper guineense. Asian Journal of Medicine and Health, 1(3), 2016, $1-8$.

[13]. D. B. Kim-kabari, I. S. Barimala, S. C. Achinewhu, and T. A. Adeniji, Effect of extracts from three indigenous spices on the chemical stability of smoked-dried catfish during storage. African Journal of Food, Agriculture, Nutrition and Development, 11(6), 2011, 174-181.

[14]. G. H. Konnning, C. Agyare, and B. Ennison, Antimicrobial activity of some medicinal plants from Ghana. Fitoterapia, 75, 2004, 65-67.

[15]. O. O. Aboaba, A. R. Ezeh, and C. L. Anabuike, Antimicrobial activities of some Nigerian spices on some pathogens. Agriculture and Biology Journal of North America, 2 (8), 2011, 1187-1193.

[16]. AOAC, Official methods of analysis. 15th ed. Arlington (VA: Association of Official Analytical Chemists, 1990).

[17]. N. Saitou, an d M Nei, The neighbor-joining method: A new method for reconstructing phylogenetic trees. Molecular Biology and Evolution, 4(4), 1987, 406-425.

[18]. J. Felsenstein, Confidence limits on phylogenies: An approach using the bootstrap. Evolution, 39 (4), $1985,783-791$.

[19]. T. H. Jukes, and c. R. Cantor, Evolution of protein molecules.In H. N. Munro (Ed) Mammalian Protein Metabolism, New York:Academic Press, 1969)

[20]. C. Akujobi, B. N. Anyanwu, C. Onyeze, and V. I. Ibekwe, Antibacterial and preliminary phytochemical screening of four medicinal plants. Journal of Applied Science, 7(3), 2004, 4328 - 4338.

[21]. S. E. Kolawole, and H. O. Obueh, Proximate and micronutrient compositions of some selected foods and diets in South-South Nigeria. Scholarly Journals of Biotechnology, 1(3), 2012, 45-48.

[22]. R. A. Olayemi, and A. Rahman, Thermal properties of some selected Nigerian soups. Agricultural Sciences 4 (5B), 2013 , $96-99$.

[23]. J. M. Jay, Modern Food Microbiology (USA: Aspen Publishers, Inc., 2000).

[24]. B. Ray, Fundamental Food Microbiology, 3rd Ed (Washington DC: CRC press, 2005).

[25]. T. E. Ogbulie, A. Uzomah, and M. N. Agbugba, Assessment of the Safety of Some On-The-Shelf Canned Food Products Using PCR-Based Molecular Technique. Nigerian Food Journal, 32(2), 2014, 81-91.

[26]. M. Liu, F. Z. Liu, Z. T. Yong-Zhi, and W. Xu, Isolation and identification of spoilage bacteria in native-chicken soup. Food Science, 32(29), 2011, 156-158.

[27]. H. M. Elmer, Extended shelf life refrigerated foods: microbiological quality and safety. Food Technology, 52(2), 2014, 57-62.

[28]. B. Lung, T. C. Baird-Parker, and G. W. Gould, The microbiological safety and quality of food (Maryland: Aspen Publishers, Inc., 2000)

[29]. B. Dogan, and K. J. Boor, Genetic diversity and spoilage potentials among Pseudomonas spp. Isolated from fluid milk products and dairy processing plants. Applied and Environmental Microbiology, 69(1), 2003, 130-138.

[30]. T. N. Nwagu, C. Amadi, and O. Alaekwe, Role of bacteria isolates in the spoilage of fermented African oil had been seed ugba. Pakistan Journal of Biological Science, 13(10), 2010, 497-503.

[31]. S. Arslen, A. Eyi, and F. Özdemir, Spoilage potentials and antimicrobial resistance of Pseudomonas spp. Isolated from cheeses. Journal of dairy Science, 94(12), 2011, 5851-5856.

[32]. S. Rawat, Food spoilage: Microorganisms and their preservation. Asian Journal of Plant Science and Research, 5(4), 2015, 47-56.

[33]. T. M. Scatamburio, A. K. Yamazi, V. Q. Cavicchioli, F. A. Pieri, and L. A. Nero, Spoilage potential of Pseudomonas species isolated from goat milk. Journal of Dairy Science, 98(2), 2015, 759-764

[34]. F. O. U. Osuala, and S. O. Anyadoh, Antibacterial activity of methanolic and ethanolic extracts of the local plants, 'Uziza' (Piper guineense). International Journal of Natural and Applied Science, 2(1), 2006, 61-64. 